\title{
Solid Waste Generation and Biogas Potential Estimation from Hotel Activities in Bali Province, Indonesia
}

\author{
I Wayan Koko Suryawan ${ }^{1 *}$, Ari Rahman ${ }^{1}$,Fatimah Dinan Qonitan ${ }^{1}$, EviSiti Sofiyah $^{\mathbf{1}}$, \\ Faculty of Infrastructure Planning, Department of Environmental Engineering, \\ UniversitasPertamina, KomplekUniversitasPertamina, JalanSinabung II, TerusanSimprug, Jakarta 12220, Indonesia \\ i.suryawan@ universitaspertamina.ac.id
}

\begin{abstract}
The aim of the research is to analyse the amount of solid waste generation, solid waste composition, methane production, carbondioxide production, and to estimate the yield of biogas production, especially in bio digester applications for material recovery facility (MRF) -especially for hotel waste in Bali Province.The study used secondary data in the form of number of beds and occupancy rates of hotels in Bali Province. Hotel solid waste generation is 2.5 L/bedday with organic waste that can be used as biodigester such as food waste and garden waste with composition respectively $31.2 \%$ and $7.8 \%$. The potential for biogas formation-was calculated based on the ultimate and proximate analysis. Each methane and carbon dioxide gas production werecalculated based on the stoichiometric equation.The results of data processing showed that the highest total solid waste generation in Badung Regency was $32.7 \pm 4$ tons/day in starred hotels and $14.7 \pm 4$ tons/day in non-star hotels. The composition of solid waste in Badung Regency consisted of kitchen waste with the generation of 12.8 tons/day and garden waste 3.1 tons/day. Result of the composition of kitchen waste and garden waste in Jembrana Regency, Tabanan Regency, and Bangli Regency was very low and had no potential for the application of bio-digesters. The highest methane gas production is in Badung Regency, Gianyar Regency and Denpasar City. Yield biogas generated/unit dry weight for hotel waste in Bali Province was $0.46 \mathrm{~kg} \mathrm{CH} / \mathrm{kg}$ dry weight with only $30 \%$ biogas content.This study showed that the hotels in the Badung Regency, Gianyar Regency, and Denpasar City areas could apply communal bio-digester technology to their kitchen waste and yard waste. This application could be applied with the addition of a special MRF for hotel facilities.
\end{abstract}

Key words: hotel waste, biogas production, bali

\section{INTRODUCTION}

Local tourist arrivals in Bali experienced highly growth from $2,038,186$ people in 2004 to $9,757,991$ people in 2018 or had increased to $479 \%$ [1][13]. This has an impact on the increasing level of occupancy in hotel.Hotels in the Province of Bali experienced an increase in occupancy from $52.1 \%$ in January 2000 to $67.1 \%$ in August 2019 for star hotels [1].
Whereas for non-star hotels, it also increased from 29.93\% in February 2007 to 38.37\% in August 2019 [1]. The existence of these hotels has positive and negative impacts. Negative impacts could be caused by inappropriate hotel solid waste management which cause the environmental pollution.

Characteristics of hotel solid waste is similar to municipal solid waste, which consists of food waste, plastic, paper, metal, glass, wood, rubber, and textile product. The emergence of hotel solid waste has increased along with the tourists visiting.Proper technology must be prepared to prevent and to minimize environmental impacts. Land pollution is mainly caused by improper disposal of solid waste management such as open dumping [2][15-18]. Since Denpasar City was selected as a city that is required to manage waste to energy [3], it is very important to do solid waste treatment that able to recover hotel solid waste. One technology that can be proposed is the application of biodigester, given the high composition of food waste and yard waste in hotels. Biodigester is a tool to decompose organic waste by means of anaerobic fermentation (airtight) converted into biogas which can be used as fuel for cooking and even into electricity[4][14].

Biogas technology basically utilizes the digestion process carried out by methanogenic bacteria whose products are in the form of methane gas $\left(\mathrm{CH}_{4}\right)$. Methane gas from the digestion of bacteria may reach $60 \%$ of the total gas produced by the biogas reactor while the rest is dominated by carbon dioxide $\left(\mathrm{CO}_{2}\right)$. Biogas energy resources on average contain $60 \%$ of methane $\left(\mathrm{CH}_{4}\right), 40 \%$ of carbon dioxide $\left(\mathrm{CO}_{2}\right)$, and about $0.2 \%$ of hydrogen sulphide $\left(\mathrm{H}_{2} \mathrm{~S}\right)$ [5]. Biogas is produced anaerobically through three stages namely hydrolysis, acidogenesis, and methanogens[6][20].

Principally, the production of methane (biogas) is depend on the ratio of carbon andnitrogen $(\mathrm{N})$ content[7][21]. The carbon element in organic material is very much required as an energy provider for anaerobic bacteria. Besides the carbon element, another element that plays an important role in this process is nitrogen $(\mathrm{N})$ because it is needed for bacterial formation/ breeding[19]. In the process of biogas formation the comparison between the amount of carbon and 
I Wayan Koko Suryawan et al., International Journal of Emerging Trends in Engineering Research, 8(9), September 2020, 5530 - 5538

nitrogen elements is crucial to the success of the biogas formation process.

To get the amount of biogas, an analysis of methane gas generation from the type of waste is needed. One method of calculation is to do proximate and ultimate analysis of waste. Estimation of methane gas generation is an effort to calculate the feasibility of the technology to be applied in hotel activities. Based on previous research, the unit price for $1 \mathrm{~kg}$ of biogas is Rp. 6,000.00. Hotel is one of the tourism sectors that has the potential to produce waste with different characteristics. This study aims to determine the generation and thecomposition of hotel solid waste, the amount of $\mathrm{CO}_{2}$ gas production and $\mathrm{CH}_{4}$ gas production, and the estimated yield of biogas production in the hotel sector in the Province of Bali.

\section{MATERIAL AND METHOD}

\subsection{Number of Beds and Hotel Occupancy}

Data on the number of beds and occupancy rates are important to be used in predicting waste generation in the hotel sector. These datawere obtained from statistics Indonesia [1]. Solid waste generation from hotel waste is 2.5 L/bed.day[8]. The number of star hotel and non-star hotel beds varies greatly by year and location (Table 1).

Hotel occupancy rates tend to be high at the beginning of the year and at the end of the year (Figure 1). Data on the number of beds and occupancy rate data is calculated to get the number of beds occupied at hotels in each area in the Province of Bali.

\subsection{Solid Waste Composition}

The composition of waste really determines the proximate and ultimate characteristics of hotel solid waste. Hotel solid waste composition that is important in this research is kitchen - and garden waste. This waste is one of the categorized as rapidly decomposable [9]. The data used in this study is data from the recent research about composition of hotel solid waste [10] (Figure 2). Waste generation data was obtained based on waste composition, then was calculated based on district and city data in Bali Province.

\subsection{Biogas Potential}

Determination of biogas production potential is based on ultimate analysis data. Because this research focusd on biodigesters using food waste and yard, the characteristics were calculated based on the composition of the waste. The ultimate and proximate analysis used from the results of previous studies [11] (Table 2). The calculation of biogas production was based on organic waste reaction as in equation 1 . The results of the reaction will produce methane gas, carbon dioxide gas, and ammonia gas. Determination of methane gas production and carbon dioxide gas was calculated based on equation 2 and 3 .

$$
\begin{aligned}
& \mathrm{C}_{\mathrm{x}} \mathrm{H}_{\mathrm{y}} \mathrm{O}_{\mathrm{z}} \mathrm{N}+\mathrm{H}_{2} \mathrm{O} \rightarrow \mathrm{CH}_{4}+\mathrm{CO}_{2}+\mathrm{NH}_{3}(1) \\
& \frac{\left(\text { Mr total } C H_{4}\right)(\text { Total dry weight })}{(\text { Mr total } \text { CxHyOzN })\left(\text { Specific weight } \mathrm{CH}_{4}\right)}(2)
\end{aligned}
$$

$\frac{\left(\mathrm{Mr} \text { total } \mathrm{CO}_{2}\right)(\text { Total dry weight })}{(\mathrm{Mr} \text { total } \mathrm{CxHyOzN})\left(\text { Specific weight } \mathrm{CO}_{2}\right)}(3)$

\section{RESULT AND DISCUSSION}

\subsection{Solid Waste Generation}

The hotel occupancy rate is very influential in determining the amount of solid waste generation. It can be seen in Table 1 and Figure 2, that Badung Regency has the highest number of beds in hotels and occupancy rates. Badung Regency hotel solid waste generation reached $32.7 \pm 4$ tons/day for star hotels and $14.7 \pm 4$ tons/day for non-star hotels. These results of hotels solid waste generation in Badung Regency are inversely proportional to Tabanan Regency, Gianyar Regency Klungkung Regency, Karangasem Regency, and Buleleng Regency which produce the highest solid waste in non-star hotels. Badung Regency contributed $85.2 \%$ of hotel waste generation to the total hotel waste in the Bali Province (Figure 4). South Bali is the busiest and most developed area in Bali, and is also the most popular among tourists famous for Kuta, Legian, Seminyak, Canggu, Nusa Dua, and the Bukit Peninsula, also the location of the NgurahRai airport [22-23].

Table 1:Number of Hotel Beds in Bali Province (BPS, 2019)

\begin{tabular}{|l|r|r|r|r|}
\hline \multirow{2}{*}{\multicolumn{1}{|c|}{ Area }} & \multicolumn{4}{|c|}{ Number of beds } \\
\cline { 2 - 5 } & \multicolumn{2}{|c|}{$\mathbf{2 0 1 7}$} & \multicolumn{2}{c|}{$\mathbf{2 0 1 8}$} \\
\cline { 2 - 5 } & Star Hotel & $\begin{array}{c}\text { Non-star } \\
\text { Hotel }\end{array}$ & Star Hotel & $\begin{array}{c}\text { Non-star } \\
\text { Hotel }\end{array}$ \\
\hline Jembrana Regency & 162 & 1195 & 184 & 1047 \\
\hline Tabanan Regency & 231 & 1739 & 270 & 1689 \\
\hline Badung Regency & 83231 & 45482 & 66654 & 40345 \\
\hline Gianyar Regency & 1463 & 10784 & 1825 & 12134 \\
\hline Klungkung Regency & 385 & 2093 & 379 & 2699 \\
\hline Bangli Regency & 0 & 582 & 0 & 471 \\
\hline Karangasem Regency & 442 & 3756 & 409 & 4499 \\
\hline Buleleng Regency & 953 & 3900 & 992 & 4941 \\
\hline Denpasar City & 7355 & 10946 & 8088 & 10942 \\
\hline Bali Province & 94222 & 80477 & 78801 & 78767 \\
\hline
\end{tabular}


I Wayan Koko Suryawan et al., International Journal of Emerging Trends in Engineering Research, 8(9), September 2020, 5530 - 5538

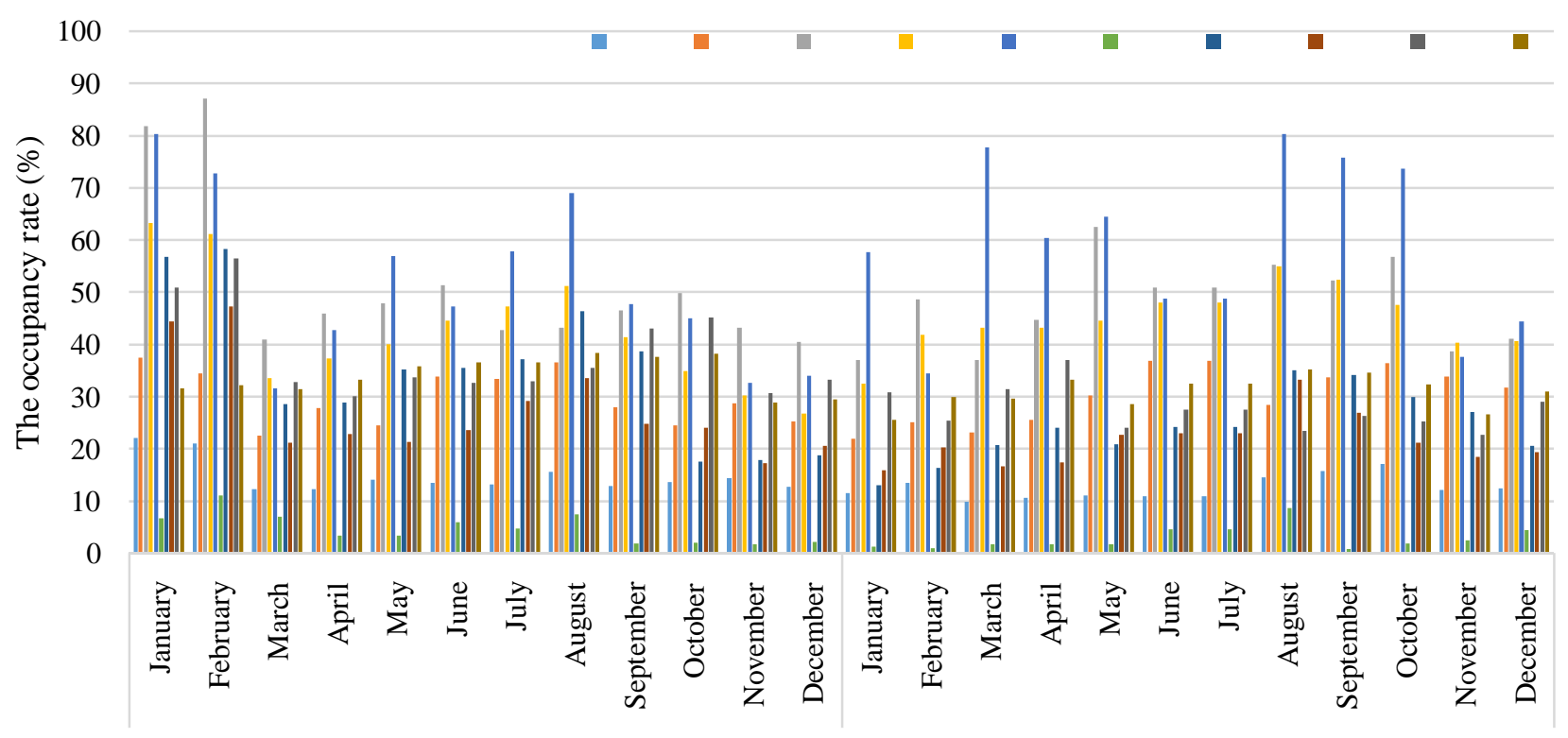

Figure 1: Hotel Occupancy Rate in Bali Province

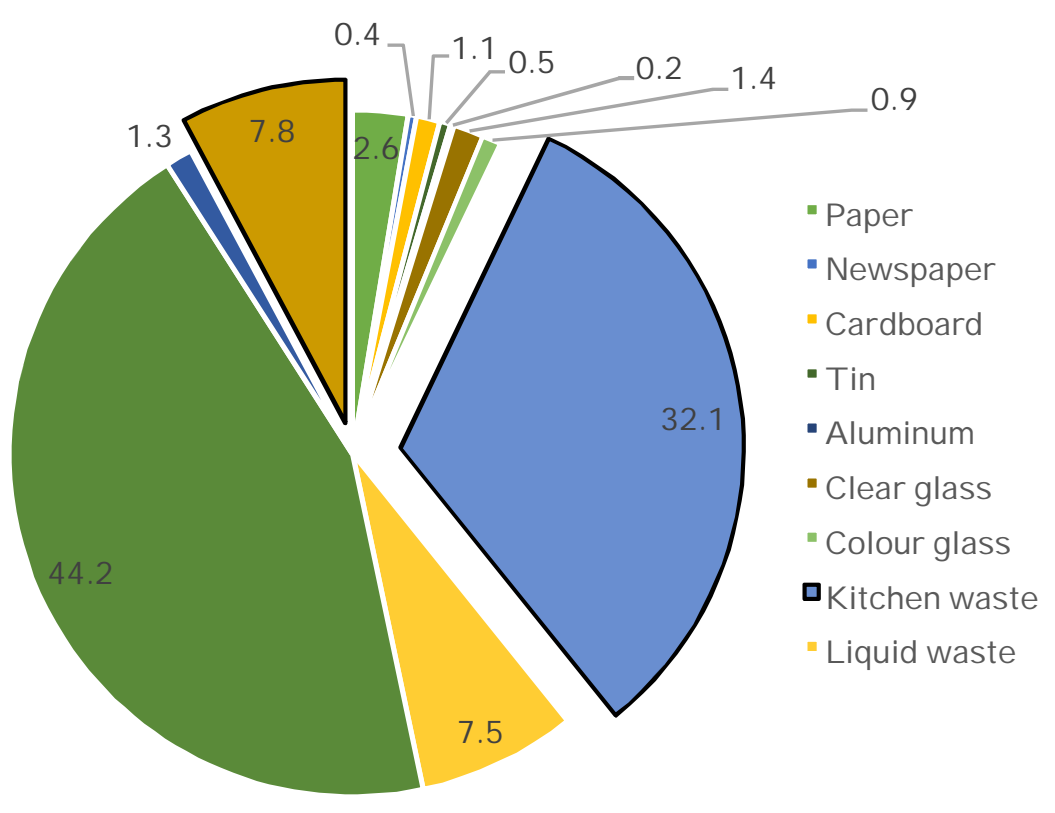

Figure 2: Composition of Hotel Trash in the Province of Bali (in \% composition) Table 2:Results of proximate and ultimate analysis of household waste [12]

\begin{tabular}{|l|c|c|c|c|c|c|c|}
\hline $\begin{array}{c}\text { Composting } \\
\text { waste }\end{array}$ & $\begin{array}{c}\mathbf{C} \\
(\boldsymbol{\%})\end{array}$ & $\begin{array}{c}\mathbf{H} \\
(\boldsymbol{\%})\end{array}$ & $\begin{array}{c}\mathbf{O} \\
(\boldsymbol{\%})\end{array}$ & $\begin{array}{c}\mathbf{N} \\
(\boldsymbol{\%})\end{array}$ & $\begin{array}{c}\mathbf{S} \\
(\boldsymbol{\%})\end{array}$ & $\begin{array}{c}\text { Moisture } \\
\text { content } \\
(\boldsymbol{\%})\end{array}$ & $\begin{array}{c}\text { Ash moisture } \\
\text { content } \\
(\boldsymbol{\%})\end{array}$ \\
\hline Food waste & 71,9 & 6,2 & 21,3 & 0,5 & 0,5 & $83,9 \%$ & $20,8 \%$ \\
\hline Yard & 62,4 & 6,6 & 30,4 & 0,4 & 0,6 & $61,7 \%$ & $84,3 \%$ \\
\hline
\end{tabular}


I Wayan Koko Suryawan et al., International Journal of Emerging Trends in Engineering Research, 8(9), September 2020, 5530 - 5538

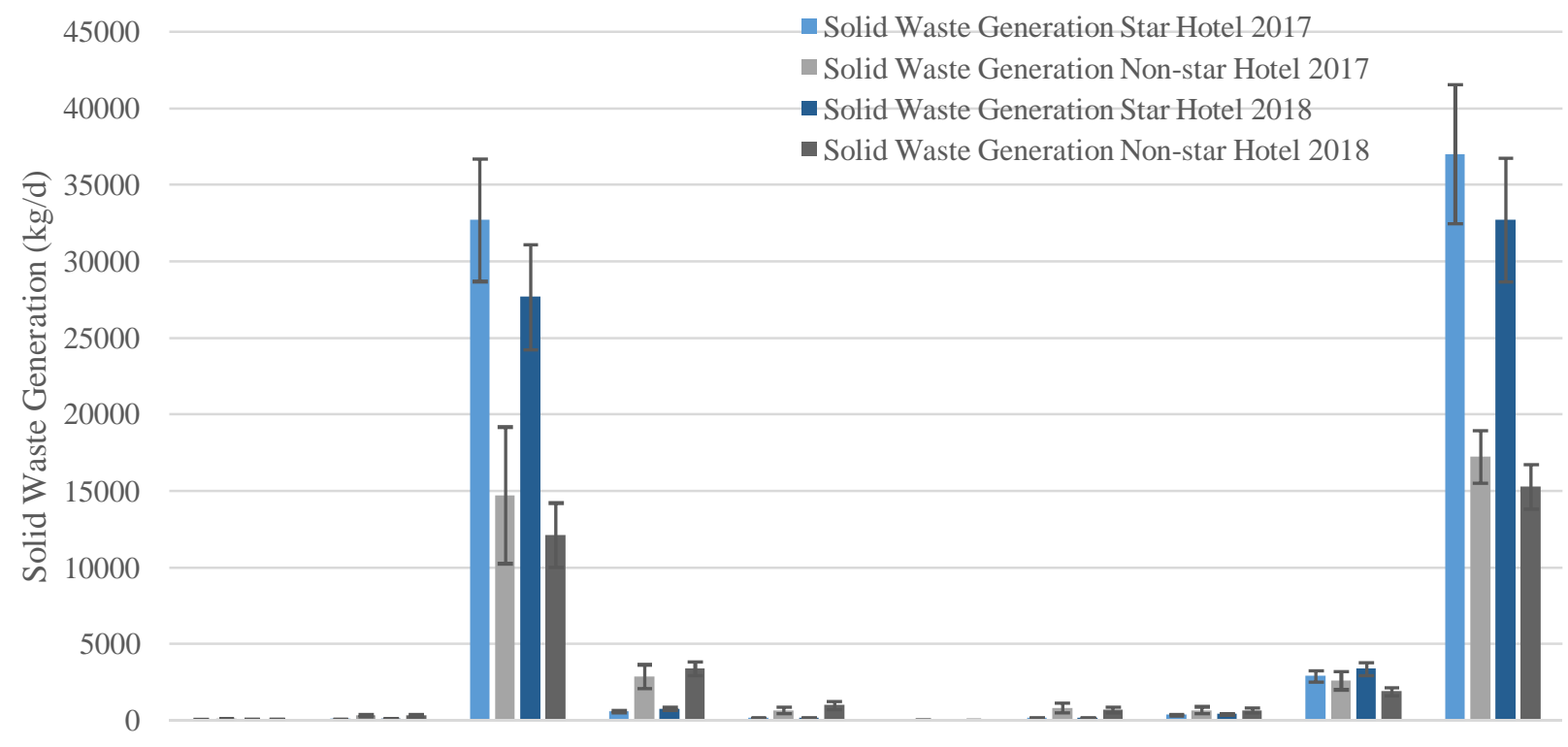

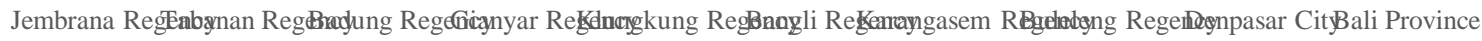

Figure 3:Hotel Solid Generation in Star Hotel and Non-Star Hotel Bali Province from 2017-2018

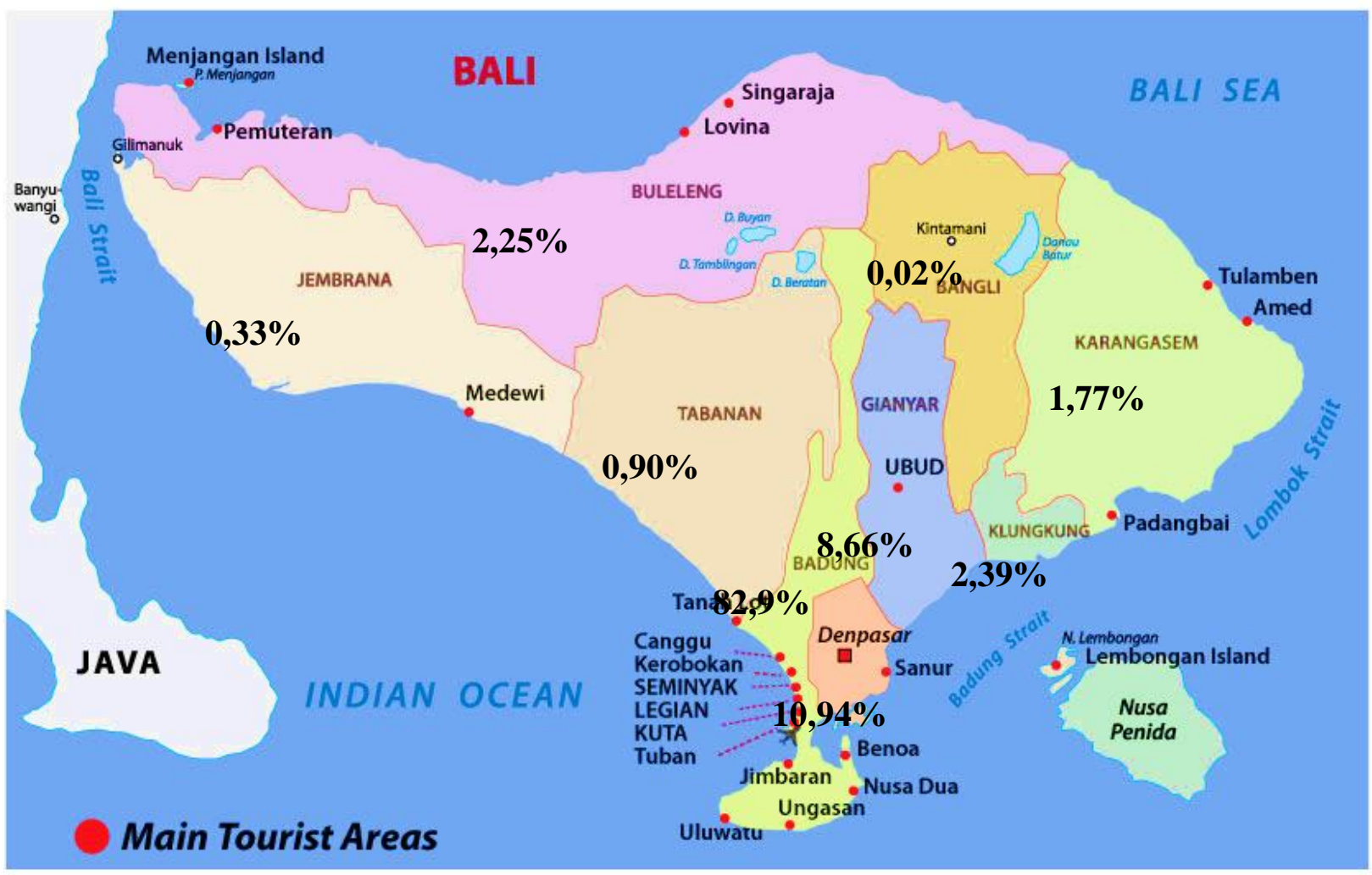

Figure 4:Distribution Contribution of Hotel Solid Waste Generation in Bali Province [11]

\subsection{Solid Waste Compositions}

Material Recovery Facility (MRF) is a recycling facility that combines several solid waste management techniques to the maximum extent possible with minimum residues such as waste sorting, 3R (reduce, reuse, and recycling), composting, and treatment facility such as anaerobic digester and incineration. MRF design can provide advantages in handling waste processing relatively quickly, efficiently and environmentally friendly, saving landfill land requirements, extending landfill life.
Energy can be recovered from the organic waste fraction (biodegradable and non-biodegradable) through the following two methods: Thermochemical conversion is through thermal decomposition of organic material to produce heat and gas energy. Biochemical conversion based on enzymatic decomposition of organic material by Microbiological activity to produce methane gas or alcohol. The thermochemical conversion process is used for waste that has a high percentage of non-biodegradable organic 
I Wayan Koko Suryawan et al., International Journal of Emerging Trends in Engineering Research, 8(9), September 2020, 5530 - 5538

material and low water content. Important technologies included in this category are incineration and pyrolysis / gasification. The biochemical conversion was chosen for waste which has a high percentage of biodegradable organic material and high water content. The main technology of this category is anaerobic digestion or often also called bio methanation. The main parameters that determine the potential for energy recovery from waste, including hotel solid waste, are the amount / quantity of waste and the physical chemical characteristics (quality) of waste. The actual energy produced will depend on the specific waste treatment and characteristics associated with the main parameters. The physical characteristics referred to are size of constituents, density and moisture content of solid waste. The smaller the size of the waste will speed up the decomposition of the solid waste. High density waste reflects organic biodegradability and high water content. On the other hand low density indicates the proportion of the presence of plastic, paper and other combustible materials. High water content causes biodegradable waste fraction to decompose faster than in dry conditions. This also shows that solid waste with high water content is not suitable for thermochemical conversion such as incineration and pyrolysis.

The composition of hotel waste in Bali Province is determined by the source of the waste. The sources of hotel waste are divided into three places namely kitchen and restaurant; guest rooms and outlets, and gardens. Waste that will be used as biodigester is leftover and rubbish from the kitchen, restaurant and garden. The life cycle of solid waste from the hotel sector in Bali Province can be seen in Figure 5. In bioconversion production, all types of organic waste can be used as substrates such as kitchen, garden, and cow manure (Wani and Rao, 2013).

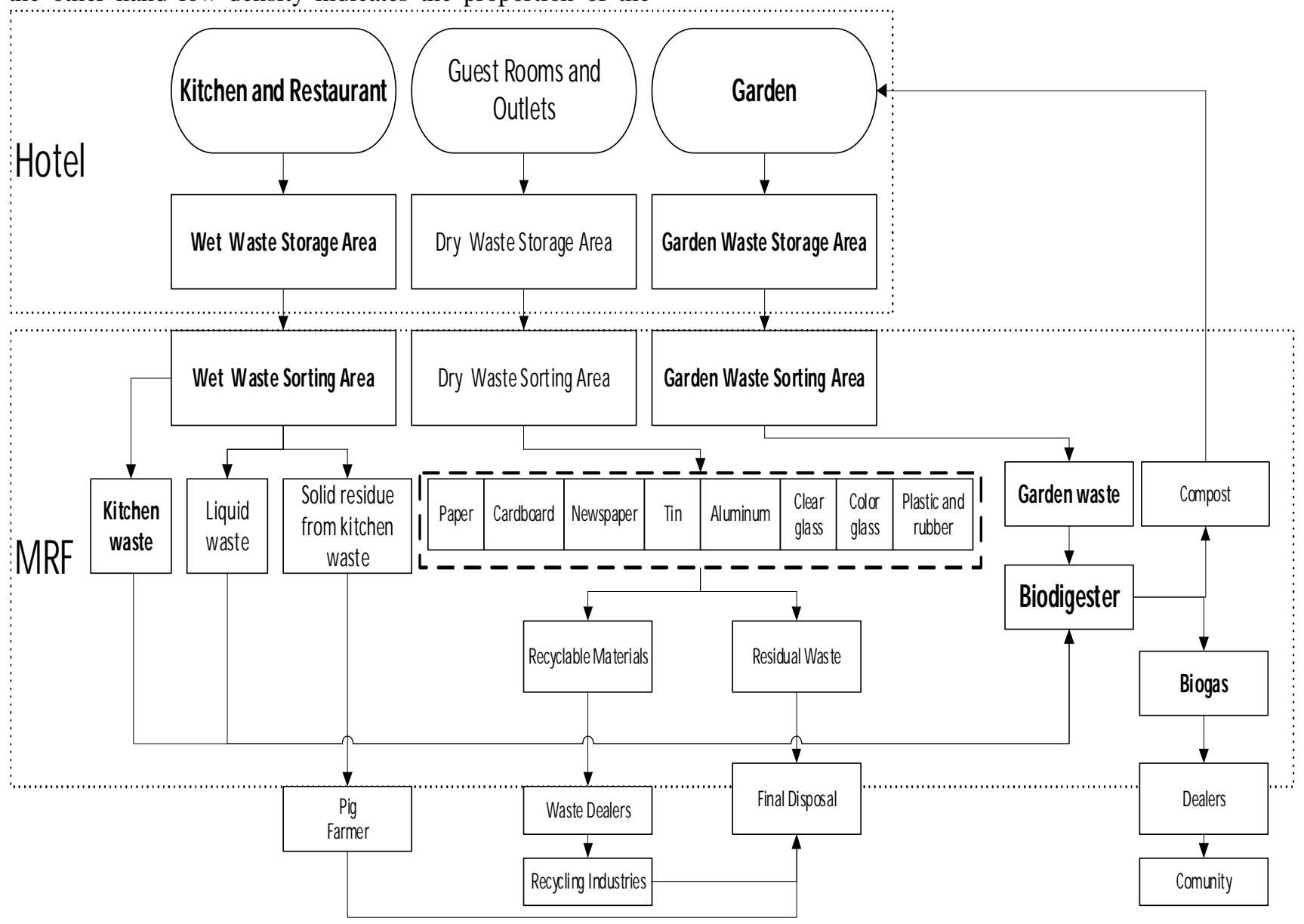

Figure 5:Life cycle of solid waste from the hotel sector in Bali Province (Modifications from Tang, 2004) 
I Wayan Koko Suryawan et al., International Journal of Emerging Trends in Engineering Research, 8(9), September 2020, 5530 - 5538

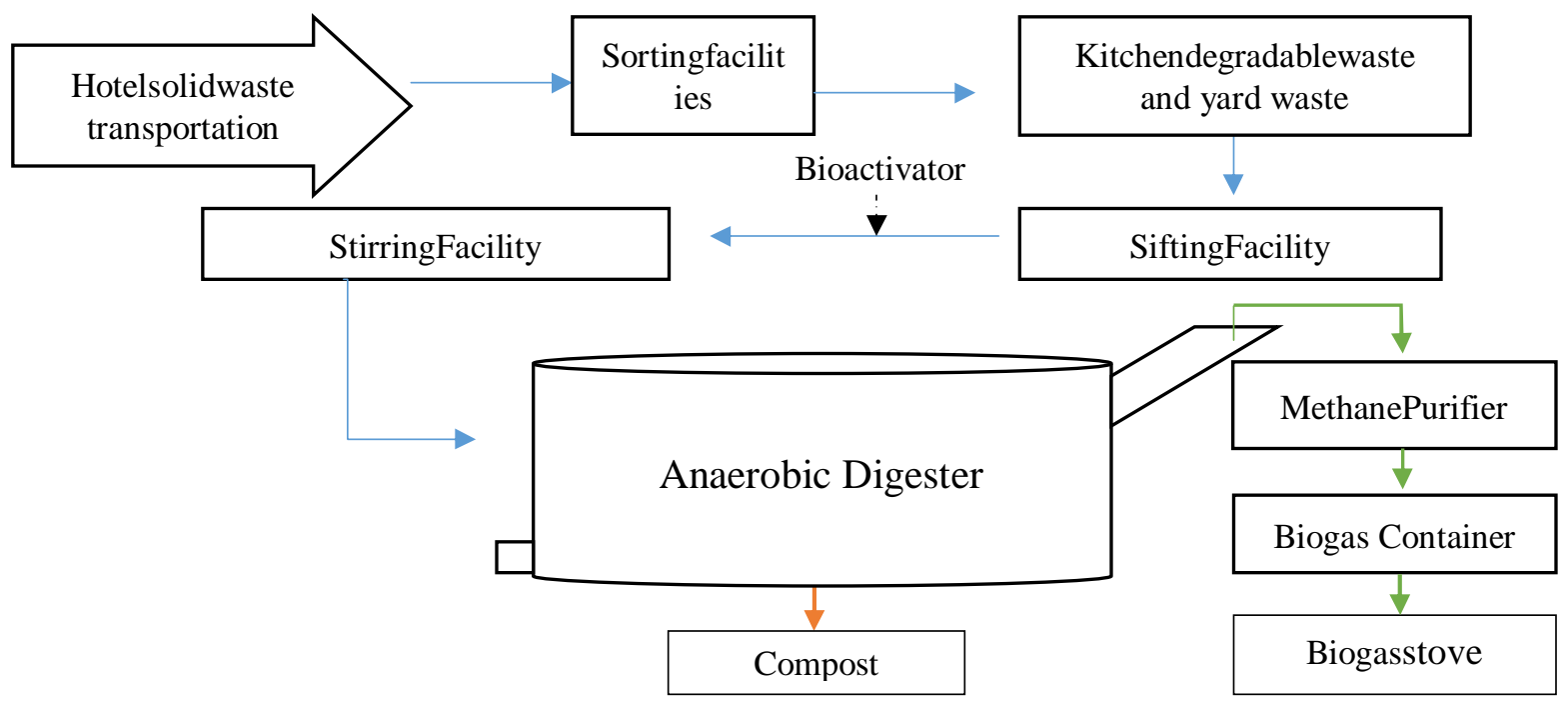

Figure 6:Diagram of the Anaerobic Digester Facility of Hotel Solid Waste

Table 3:Calculation of Hotel Solid Waste Composition in Bali Province

\begin{tabular}{|c|c|c|c|c|c|c|c|c|c|c|c|c|}
\hline \multirow[b]{2}{*}{ Area } & \multicolumn{12}{|c|}{ Weight composition (kg) } \\
\hline & Paper & Newspaper & Cardboard & Tin & Aluminum & $\begin{array}{l}\text { Clear } \\
\text { glass }\end{array}$ & $\begin{array}{l}\text { Color } \\
\text { glass }\end{array}$ & $\begin{array}{l}\text { Kitchen } \\
\text { waste }\end{array}$ & $\begin{array}{l}\text { Liquid } \\
\text { waste }\end{array}$ & $\begin{array}{l}\text { Solid } \\
\text { residue } \\
\text { from } \\
\text { kitchen } \\
\text { waste }\end{array}$ & $\begin{array}{l}\text { Garden } \\
\text { waste }\end{array}$ & $\begin{array}{l}\text { Plastic } \\
\text { and } \\
\text { rubber }\end{array}$ \\
\hline Jembrana Regency & 4,1 & 0,6 & 1,7 & 0,8 & 0,3 & 2,2 & 1,4 & 51,0 & 11,9 & 70,3 & 12,4 & 2,07 \\
\hline Tabanan Regency & 11,3 & 1,7 & 4,8 & 2,2 & 0,9 & 6,1 & 3,9 & 139,0 & 32,5 & 191,4 & 33,8 & 5,63 \\
\hline Gianyar Regency & 108,1 & 16,6 & 45,8 & 20,8 & 8,3 & 58,2 & 37,4 & 1335,2 & 312,0 & 1838,5 & 324,4 & 54,07 \\
\hline $\begin{array}{l}\text { Klungkung } \\
\text { Regency }\end{array}$ & 29,9 & 4,6 & 12,6 & 5,7 & 2,3 & 16,1 & 10,3 & 368,8 & 86,2 & 507,8 & 89,6 & 14,93 \\
\hline Bangli Regency & 0,2 & 0,0 & 0,1 & 0,0 & 0,0 & 0,1 & 0,1 & 2,8 & 0,7 & 3,9 & $\mathbf{0 , 7}$ & 0,11 \\
\hline $\begin{array}{l}\text { Karangasem } \\
\text { Regency }\end{array}$ & 22,2 & 3,4 & 9,4 & 4,3 & 1,7 & 11,9 & 7,7 & 273,6 & 63,9 & 376,7 & 66,5 & 11,08 \\
\hline Bali Province & 1248,5 & 192,1 & 528,2 & 240,1 & 96,0 & 672,3 & 432,2 & 15413,8 & 3601,4 & 21224,0 & 3745,4 & 624,24 \\
\hline
\end{tabular}

Calculation of hotel solid waste composition is based on Figure 5. Each weight of waste based on composition can be seen in Table 3. Organic waste can be categorized into easily biodegradable, consist of kitchen waste, food waste, vegetable waste, fruit and hardly biodegradable organic waste, like, paper, textiles, rubber, wood, and leather. While non-biodegradable inorganic waste including metals, iron, glass, pottery [11]. The main components of biogas are methane ranging from $50-75 \%$, then carbon dioxide ranging from $25-45 \%$, Nitrogen $0-10 \%$, hydrogen $0-1 \%$, hydrogen sulfide $0-3 \%$, oxygen $0-2 \%$ [12].

Figure 6 shows a diagram of the facility of Anaerobic Digester, based on existing condition of solid waste in hotel activities which is relatively generated wet solid waste, the appropriate energy recovery technology applied is Anaerobic Digester. Anaerobic Digester is a treatment process that needs to be used to degrade and stabilize sludge. In general Anaerobic Digester has long been used, especially in rural areas, to produce biogas needed for cooking and lighting. As for large-scale (urban), there are currently many developed countries in Europe that apply Anaerobic Digester method to manage their urban waste while getting by-products in the form of biogas that is used to drive electricity generators. Non-organic biodegradation is a common thing in nature, this process always involves microorganisms. If organic matter is broken down by aerobic bacteria, the process is called oxidation and produces $\mathrm{CO}_{2}$ and $\mathrm{H}_{2} \mathrm{O}$ Anaerobic Digester is carried out by anaerobic microorganisms, without oxygen, then the organic material is degraded by microbes into $\mathrm{CO}_{2}$ and Methane (Mosey, 1976). Anaerobic Digester on organic matter is synergistically by a group of microorganisms. The digestive process consists of 4 stages: hydrolysis, acidogenesis, acetogenesis, and methanogenesis. For further utilization, namely to be used as raw material for fuel cells, the methane used must be pure. For this purpose the impurity component must be removed, one of the most dominant components is $\mathrm{CO}_{2}$. Figure 6 shows that in the 
I Wayan Koko Suryawan et al., International Journal of Emerging Trends in Engineering Research, 8(9), September 2020, 5530 - 5538

facility there must be a methane purifier that can remove other impurities. Study of Iriani, and Heryadi (2014) showed $\mathrm{CO}_{2}$ levels of biogas after purification dropped by $35.04 \%$ and after $\mathrm{CH}_{4}$ content purified increased by $34.01 \%$ with 730 grams of activated carbon.

In the process of land selection for Anaerobic Digester Facility, physical and non-physical criteria must be met. The requirements used to use the approach of the selection of Anaerobic Digester Facility locations, namely SNI No. 033241-1994. The purpose of choosing the location of the Anaerobic Digester Facility is to establish and operate an Anaerobic Digester expected not to cause a decrease in the quality of the soil environment, groundwater, and also not cause health problems in humans.

\subsection{Methane and Carbon dioxide production}

Besides the composition of hotel solid waste, physical and chemical characteristics of hotel solid waste are also important in the waste management process. Chemical characteristics explain the chemical structure of solid waste, which consists of several elements, such as: $\mathrm{C}, \mathrm{N}, \mathrm{O}, \mathrm{P}, \mathrm{H}$, and $\mathrm{S}$. Indonesia does not yet have a default DOC number (IPCC, 2007). DOC number is determined by ultimate analysis (dry base) of the elementary components $\mathrm{C}, \mathrm{H}, \mathrm{N}$, $\mathrm{O}, \mathrm{S}$, ash (reduce, reuse, and recycle). Indonesia, in estimating methane emissions, is still using the default IPCC, 2007, because it does not yet have a country specific composition of waste dumped at the landfill. Calculation of total decomposable organic constituents is based on data in Table 2. The calculation results can be seen in Table 4. The calculation results showed a very high $\mathrm{C} / \mathrm{N}$ ratio of 324/1.

Empirically it is known that the most favourable $\mathrm{C} / \mathrm{N}$ ratio is in the range of 20-30:1 (Dioha et al. 2013). If the $\mathrm{C} / \mathrm{N}$ ratio is too high, biogas production is not optimal (Roy et al. $2010)$. If the $\mathrm{C} / \mathrm{N}$ ratio is too low $(\leq 9)$ ammonia will be formed which will cause the decomposition process not run optimally (Kayhanian, 1999). So that in processing applications it is necessary to add nutrients such as fertilizer to increase the $\mathrm{N}$ content.

The principle of biogas production is anaerobic organic matter decomposition (oxygen free) that produces gas which is mostly methane (which has flammable properties) and carbon dioxide in equation 1 . The equation is based on Table 4 and is balanced to be as in equation 4 .

$\mathrm{C}_{324} \mathrm{H}_{27} \mathrm{O}_{76} \mathrm{~N}+280 \mathrm{H}_{2} \mathrm{O} \rightarrow 146 \mathrm{CH}_{4}+178 \mathrm{CO}_{2}+\mathrm{NH}_{3}$

Based on Table 5, the generated gas yield dry based unit for hotel waste in the province of Bali is $0.46 \mathrm{~kg} \mathrm{CH} 4 / \mathrm{kg}$. The results of calculations in hotel waste are greater than ruminant livestock sheep by $0.0184 \mathrm{~kg} \mathrm{CH} 4 / \mathrm{kg}$. Wims et al. (2010) reported that $\mathrm{CH}_{4}$ production per cow per day $(+42$ $\mathrm{g})$, per kilogram of milk yield $(+3.5 \mathrm{~g} / \mathrm{kg}$ of milk), per kilogram of milk solids ( $+47 \mathrm{~g} / \mathrm{kg}$ of milk solids).

Table 4: MSW Compositions in Indonesia's Cities

\begin{tabular}{|l|r|r|r|r|c|c|c|r|}
\hline \multirow{2}{*}{ Area } & \multicolumn{4}{|c|}{$\begin{array}{c}\text { Total decomposable organic } \\
\text { constituents }\end{array}$} & \multicolumn{4}{c|}{ Mol. Ratio (nitrogen =1) } \\
\cline { 2 - 11 } & \multicolumn{1}{|c|}{ C } & \multicolumn{1}{|c|}{ H } & \multicolumn{1}{c|}{ O } & \multicolumn{1}{c|}{ N } & C & H & O & N \\
\hline Jembrana Regency & 13,73 & 1,14 & 3,21 & 0,04 & 324 & 27 & 76 & 1 \\
\hline Tabanan Regency & 37,40 & 3,09 & 8,75 & 0,12 & 324 & 27 & 76 & 1 \\
\hline Badung Regency & 3438,04 & 284,25 & 804,58 & 10,62 & 324 & 27 & 76 & 1 \\
\hline Gianyar Regency & 359,24 & 29,70 & 84,07 & 1,11 & 324 & 27 & 76 & 1 \\
\hline Klungkung Regency & 99,22 & 8,20 & 23,22 & 0,31 & 324 & 27 & 76 & 1 \\
\hline Bangli Regency & 0,76 & 0,06 & 0,18 & 0,00 & 324 & 27 & 76 & 1 \\
\hline Karangasem Regency & 73,61 & 6,09 & 17,23 & 0,23 & 324 & 27 & 76 & 1 \\
\hline Buleleng Regency & 93,20 & 7,71 & 21,81 & 0,29 & 324 & 27 & 76 & 1 \\
\hline Denpasar City & 453,53 & 37,50 & 106,14 & 1,40 & 324 & 27 & 76 & 1 \\
\hline Bali Province & 4147,09 & 342,87 & 970,51 & 12,80 & 324 & 27 & 76 & 1 \\
\hline
\end{tabular}

Table 5:Theoretical amount of gas generated from waste generation in each regency in Bali Province

\begin{tabular}{|c|c|c|c|c|c|c|}
\hline \multirow[t]{2}{*}{ Area } & $\begin{array}{l}\text { Solid } \\
\text { waste } \\
\text { (dried } \\
\text { basis) } \\
\end{array}$ & $\begin{array}{c}\text { Methane } \\
\text { specific } \\
\text { weight }\end{array}$ & $\begin{array}{l}\text { Carbon dioxide } \\
\text { specific weight }\end{array}$ & $\begin{array}{l}\text { Methane } \\
\text { production }\end{array}$ & $\begin{array}{c}\text { Carbon } \\
\text { production }\end{array}$ & $\begin{array}{c}\text { Yield gas } \\
\text { generated/solid } \\
\text { waste }(\text { dried } \\
\text { basis) }\end{array}$ \\
\hline & kg & $\mathrm{kg} / \mathrm{m}^{3}$ & $\mathrm{~kg} / \mathrm{m}^{3}$ & kg & kg & $\mathrm{kg} \mathrm{CH} / \mathrm{kg}$ \\
\hline Jembrana Regency & 10,2 & \multirow[t]{2}{*}{0,7817} & \multirow[t]{2}{*}{1,978} & 4,7 & 15,6 & \multirow{2}{*}{0,46} \\
\hline Tabanan Regency & 27,8 & & & 12,7 & 42,4 & \\
\hline
\end{tabular}


I Wayan Koko Suryawan et al., International Journal of Emerging Trends in Engineering Research, 8(9), September 2020, 5530 - 5538

\begin{tabular}{|c|c|c|c|}
\hline Badung Regency & 2558,8 & 1165,5 & 3895,3 \\
\hline Gianyar Regency & 267,4 & 121,8 & 407,0 \\
\hline Klungkung Regency & 73,8 & 33,6 & 112,4 \\
\hline Bangli Regency & 0,6 & 0,3 & 0,9 \\
\hline $\begin{array}{l}\text { Karangasem } \\
\text { Regency }\end{array}$ & 54,8 & 25,0 & 83,4 \\
\hline Buleleng Regency & 69,4 & 31,6 & 105,6 \\
\hline Denpasar City & 337,5 & 153,7 & 513,9 \\
\hline Bali Province & 3086,6 & 1405,8 & 4698,7 \\
\hline
\end{tabular}

Different sources of biomass or solid waste of course will produce different quantities of biogas. The results of calculations in this study showed that the biogas content is only $30 \%$. Biogas can be burnt if there is a minimum of $57 \%$ methane content [13]. Meanwhile, according to [14] biogas can be burnt if the methane content is at least $60 \%$. Biogas with $65-70 \%$ methane content has a heating value equal to $5200-5900 \mathrm{Kcal} / \mathrm{m} 3$ of heat energy equivalent to $1.25 \mathrm{KwJ}$ of electricity [6]. The process of purifying biogas using membranes is very good at operating pressures of 5-7 bar [15]. According to [16] there are several methods of biogas purification $\left(\mathrm{CO}_{2}\right.$ removal), including: physical absorption, chemical absorption, adsorption, separation with membranes, cryogenic and chemical conversion into other compounds. Absorption is the separation of a particular gas from a mixture of gases by transferring a massake in a liquid. This is done by delivering the flow of gas with liquid which has a different solvent selectivity from the gas to be separated. The selection of separation technology will be depend on the technical and economic feasibility [17].

\section{CONCLUSION}

The results of this study showed that the formation of the biogas in Badung Regency, Gianyar Regency and Denpasar City were very suitable for the application of communal biodigester. Yield gas generated/solid waste (dried basis) unit for hotel solid waste has a value of $0.46 \mathrm{~kg} \mathrm{CH}_{4} / \mathrm{kg}$ with only $30 \%$ of biogas content. The high amount of rubbish from Badung Regency causes the importance of implementing a special MRF for hotels. Besides that, Denpasar City is also one of the cityregulated in Perpres 35 of 2018 that also has the potential to reduce waste generation from hotel facilities by using biodigesters.

\section{REFERENCES}

1. BPS. (2019). https://bali.bps.go.id/subject/16/pariwisata.html\#subjek ViewTab3. [Accessed on 18-10-2019]

2. Suryawan, I. W. K., Prajati, G., \&Afifah, A. (2019). Bottom and fly ash treatment of medical waste in cinerator from community health centres with solidification/stabilization. AIP Conference Proceedings, 2114(1), 050023. DOI : 10.1063/1.5112467.
3. Peraturan Presiden (President Regulation) RI No. 35 2018.

PercepatanPembangunanInstalasiPengolahSampahMen jadiEnergiListrikBerbasisTeknologiRamahLingkungan.

4. Wresta, A., Andriani, D., Saepudin, A., \&Sudibyo, H. (2015). Economicanalysis of cowmanurebiogas as energy source for electricity power generation in small scale ranch. Energy Procedia, 68, 122-131. DOI: 10.1016/j.egypro.2015.03.240.

5. Kayhanian, M., \&Hills, D. J. (1988). Membrane purification of an aerobic digester gas. Biological wastes, 23(1), 1-15. DOI : 10.1016/02697483(88)90040-7.

6. Veziroglu, T.N. 1991. Hydrogen technology for every needs of human settlement. Int. Journal Hydrogen Energy, 12:99. DOI : 10.1016/0360-3199(87)90086-3. DOI: $10.1016 / 0360-3199(87) 90086-3$.

7. Tanimu, M. I., Ghazi, T. I. M., Harun, R. M., \& Idris, A. (2014). Effect of carbon to nitrogen ratio of food waste on biogas methane production in a batch mesophilicanaerobic digester. International Journal of Innovation, Management and Technology, 5(2), 116. DOI: 10.7763/IJIMT.2014.V5.497.

8. Damanhuri, E., Padmi, T. (2010). Diktat KuliahPengelolaanSampah,. Institut Teknologi Bandung. Bandung

9. Tchobanoglous, G., Theisen, H., \& Vigil, S. (1993). Integrated Solid Waste. Management. Singapore: Mc Graw-Hill Book.

10. Tang, J. (2004). A case study of a hotelsolidwaste management program in Bali, Indonesia (Master'sthesis, University of Waterloo).

5. Kayhanian, M. (1999). Ammonia inhibition in highsolids biogasification: an overview and practical solutions. Environmental technology, 20(4), 355-365. DOI : $10.1080 / 09593332008616828$.

6. Hammad S.M.D. 1999. Integrated environmental and sanitary engineering project at Mirzapur. Journal of Indian Water Work Association 28:231- 236

7. Hessami M.A., Christensen S. \& Gani R. 1996. Anaerobic digestion of household organic waste to produce biogas. Renewable Energy. 9(1-4) : 1-4, 954957. DOI : 10.1016/0960-1481(96)88438-2.

8. Nadliriyah, N., \& Triwikantoro, T. (2014). Pemurnian produk biogas dengan metode absorbsi menggunakan 
larutan $\mathrm{Ca}(\mathrm{OH}) 2$. Jurnal Sains dan Seni ITS, 3(2), B107-B111. DOI: 10.12962/j23373520.v3i2.6881.

9. Kapdi, S. S., V.K. Vijay, S.K. Rajesh \& R.Prasad. 2005. Biogas scrubbing, compression and storage: perspective and prospectus in indian context. Renewable Energy. 30, 1196 - 1199. DOI : 10.1016/j.renene.2004.09.012.

10. Naquibatin, N., Ghevanda, I., Riska, A.B., Nurkumala, E., \& Triwikantoro. 2013. Pemurnian Produk Biogas Dengan Metode Filtering Menggunakan $\mathrm{Ca}(\mathrm{OH}) 2$ dari Batu Kapur Alam. Seminar Nasional Fisika. ISSN 2088-4176

11. Bali Map. Main Touristic Areas on Bali. https://www.bali.com/media/image/766/bali-map.jpg [Accessed on 11-12-2019]

12. Bourion, V., Heulin-Gotty, K., Aubert, V., Tisseyre, P., Chabert-Martinello, M., Pervent, M., Delaitre, C., Vile, D., Siol, M., Duc, G., Brunel, B., Burstin, J., Lepetit, M., \& Brunel, B. (2018). Co-inoculation of a pea corecollection with diverse rhizobial strains shows competitiveness for nodulation and efficiency of nitrogen fixation are distinct traits in the interaction. Frontiers in plant science, 8, 2249. DOI: 10.3389/fpls.2017.02249.

13. DepartemenPekerjaanUmum. SNI 03-3241-1994 about Tata Cara Pemilihan Lokasi Tempat Pembuangan Akhir Sampah (Procedure for selecting the location of the final landfill site). Jakarta, 1994.

14. Dioha, I. J., Ikeme, C. H., Nafi'u, T., Soba, N. I., \& Yusuf, M. B. S. (2013). Effect of carbon to nitrogen ratio on biogas production. International Research Journal of Natural Sciences, 1(3), 1-10.

15. IPCC. (2007). Climate Change 2007; Mitigation of Climate Change. Cambridge. University Press, Cambridge.

16. Iriani, P., \& Heryadi, A. (2014). Pemurnian Biogas Melalui Kolom Beradsorben Karbon Aktif. Sigma-Mu, 6(2), 36-42.
17. Mosey, F. E. (1976). Assessment of the maximum concentration of heavy metals in crude sewage which will not inhibit the anaerobic digestion of sludge. Water Pollution Control.

18. Roy, D., Hassan, K., \& Boopathy, R. (2010). Effect of carbon to nitrogen $(\mathrm{C}: \mathrm{N})$ ratio on nitrogen removal from shrimp production waste water using sequencing batch reactor. Journal of industrial microbiology \& biotechnology, 37(10), 1105-1110. DOI : 10.1007/s10295-010-0869-4.

19. Wani, K. A., \& Rao, R. J. (2013). Bioconversion of garden waste, kitchen waste and cow dung into valueadded products using earthworm Eisenia fetida. Saudi Journal Of Biological Sciences, 20(2), 149-154. DOI: 10.1016/j.sjbs.2013.01.001.

20. Wims, C. M., Deighton, M. H., Lewis, E., O'Loughlin, B., Delaby, L., Boland, T. M., \& O’Donovan, M. (2010). Effect of pregrazing herbage mass on methane production, dry matter intake, and milk production of grazing dairy cows during the mid-season period. Journal of Dairy Science, 93(10), 4976-4985. DOI: 10.3168/jds.2010-3245.

21. Yodi., Suryawan, I. W. K., \& Afifah, A. S. (2020, January). Estimation of Green House Gas (GHG) emission at TelagaPunggur land fill using triangular, Land GEM, and IPCC methods. In Journal of Physics: Conference Series (Vol. 1456, No. 1, p. 012001). IOP Publishing.

22. E. Ahmed and H. M. Abduljalil, "Effect of NH2 substituent group on PC61BM properties using DFT," Int. J. Emerg. Trends Eng. Res., vol. 7, no. 8, pp. 183190, 2019.

23. S. Chatterjee, "3D Modeling\&Numerical Simulation of Heat transfer of Back-pack Thermoelectric," Int. J. Emerg. Trends Eng. Res., vol. 6, no. 8, pp. 53-61, 2018. 